Marquette University

e-Publications@Marquette

College of Education Faculty Research and

Publications

Education, College of

$4-1-2016$

\title{
Can the Church Be a Virtuous Hearer of Women?
}

Mary E. Carlson

Marquette University, mary.carlson@marquette.edu

Published version. Journal of Feminist Studies in Religion, Vol. 32, No. 1 (Spring 2016): 21-36. DOI. (C) 2016 Indiana University Press. Used with permission. 


\title{
CAN THE CHURCH BE A VIRTUOUS HEARER OF WOMEN?
}

\author{
Mary Carlson
}

In 1972, the National Conference of Catholic Bishops attempted to address concerns raised by Vatican II regarding the treatment of women in the Church. The plan was to produce a pastoral letter on "The Role of Women in Society and the Church." Twenty-two years, hundreds of revised pages, and four drafts later, it produced a disappointing fourteen-page pamphlet, Strengthening the Bonds of Peace. Using this pastoral as a case study, Carlson asks, can the Church be a virtuous hearer of women? The question is meant to determine if there is an injustice being done and stems from the virtue ethics theory of Miranda Fricker. If there is no injustice, then we must look at the issue in a new way. However, if an injustice is being done, Carlson proposes a way to reapproach women through the hermeneutic of lived experience using Fricker's remedy of virtuous hearing.

In 1972, the National Conference of Catholic Bishops (NCCB), still caught up in the idealism of Vatican II, tried to address concerns the council raised regarding the treatment of women in the Church. The plan was to dialogue, study, pray, and consult with Catholic clergy, theologians, and women from all walks of life and to produce a pastoral letter on "The Role of Women in Society and the Church." Twenty-two years, hundreds of revised pages, and four drafts later, NCCB sent to parishes a disappointing fourteen-page pamphlet entitled Strengthening the Bonds of Peace. ${ }^{1}$

${ }^{1}$ National Council of Catholic Bishops (NCCB), US Catholic Conference Committee on Women in Society and in the Church, Strengthening the Bonds of Peace (Washington, DC: USCC 
While others, such as Lisa Sowle Cahill and Elisabeth Schüssler Fiorenza, ${ }^{2}$ have addressed the rightful role of women in the Church through the hermeneutical lenses of early Church tradition/teaching, scriptural studies, and reason/natural law, this paper addresses women's role through a fourth pillar of Christian ethical reflection-lived experience. Using the history of the writing of the pastoral letter on women as a case in point, ${ }^{3}$ the particular question raised here is: assuming that the Church desires to act virtuously, does the Church hierarchy practice virtuous hearing with women? The question is meant to determine if there is an injustice being done and is rooted in Miranda Fricker's virtue ethics theory. ${ }^{4}$ If there is no injustice, then we must look at the issue in a new way. However, if an injustice is being done, would it be possible to apply Fricker's proposed remedy of virtuous hearing within a framework that has precedent in Church history? If so, it may give the Church hierarchy a way to reapproach women (and possibly other marginalized groups) through the hermeneutic of lived experience.

The first part of this paper examines the question of the Church's possible justice or injustice toward women, using a brief history of the American bishops' attempt to produce a pastoral letter on women as a case study (based largely on Marvin Mich's work, ${ }^{5}$ physical copies of the documents when available, and drafts of the pastoral published in the Catholic News Service's Documentary Service Origins). The second part briefly explains elements of Fricker's theory regarding testimonial and hermeneutical injustice. The third part notes some ideas of how the Church, in the interest of justice and the common good, might begin to validate women's lived experience and includes an application of Fricker's theory of virtuous hearing, which may be worthy of further investigation.

Inc., 1994). The only hint that this pamphlet addressed women's concerns was that the cover depicted women.

${ }^{2}$ See, for example, Lisa Sowle Cahill, "Natural Law, a Feminist Reassessment," in Is There a Human Nature? ed. Leroy S. Rouner (Notre Dame, IN: University of Notre Dame Press, 1997), 78-91. Also see Elisabeth Schüssler Fiorenza, "Word, Spirit, and Power: Women in Early Christian Communities," in Women of Spirit: Female Leadership in the Jewish and Christian Traditions, ed. Rosemary Ruether and Eleanor McLaughlin (New York: Simon and Schuster, 1979), 72-99.

${ }^{3}$ NCCB, Strengthening the Bonds of Peace.

${ }^{4}$ Miranda Fricker, Epistemic Injustice: Power and the Ethics of Knowing (New York: Oxford University Press, 2007).

${ }^{5}$ Marvin L. Krier Mich, "Sexism: Women’s Voices Silent No Longer," in Catholic Social Teaching and Movements (Mystic, CT: Twenty-Third Publications, 1998), 347-84. 


\section{A Brief History of the NCCB's Attempted Pastoral Letter on Women in Church and Society}

While more than a brief summary of the twenty-two year process and the contents of the drafts is beyond the scope of this paper, some relevant highlights follow. Mich begins his account of the history of the pastoral quoting Donal Dorr, reflecting upon one hundred years of Catholic social teaching, as saying that perhaps the biggest lacuna in the Church's social teaching is its failure to provide an adequate treatment of the issue of justice for women. ${ }^{6}$

In 1972, the NCCB (later called the US Conference of Catholic Bishops, or USCCB, used here interchangeably) formed an ad hoc committee charged with addressing women's concerns and then recommending actions. With input from a wide variety of women, they developed a survey, which they conducted in 1977. In 1982, the committee recommended that the NCCB formally address the concerns women raised, and in 1984, listening sessions were held around the country, eventually involving 75,000 women from one hundred dioceses, sixty college campuses, and forty-five military bases. The committee charged with writing a "pastoral document" was made up of six bishops and seven women (mostly from academia, but representing women who were single, married, vowed religious, and mothers). The intention to enter into dialogue honestly with women from all walks of life (along with questions anticipating elements of testimonial and hermeneutical justice/ injustice) seems reflected in the questions asked: ${ }^{7}$

1. As you reflect upon your experience as a Catholic woman, what stands out for you?

2. In what ways do you feel appreciated as a woman in the Church? In society?

3. In what ways do you feel oppressed/discriminated against in the Church? In society?

4. As you reflect upon your personal experiences, what do you find contributes most to the reconciliation (harmony, affirmation, dignity, healing) of women in the Church? In society?

5. As you reflect upon your personal experiences, what do you find contributed the most to the alienation (abuse, divisiveness, dehumanization) of women in the Church? In society?

${ }^{6}$ Ibid., 247.

${ }^{7}$ NCCB, Ad Hoc Committee, Partners in the Mystery of Redemption: A Pastoral Response to Women's Concerns for Church and Society (Washington, DC: US Catholic Conference, 1988), 87. I have edited the questions slightly for length. 
6. As you reflect upon your personal experiences, what issues/ themes emerge as the most important for development of the bishops' pastoral letter on women in the Church and society?

Since women are not a monolithic entity, upon publication, their response was not universal. ${ }^{8}$ However, while some women offered support for traditional Church teaching, more asked the Church to address perceived discrimination within the Church, and beyond that, to offer contrition. In 1988, the NCCB issued its first draft, Partners in the Mystery of Redemption: A Pastoral Response to Women's Concerns for Church and Society, a ninety-nine page document. ${ }^{9}$

Partners in the Mystery of Redemption contained a report of what the committee heard through its extensive listening process, a reflection of Catholic thought, and a response intended to seek remedies to injustices and to promote positive values advocated by women. The four headings in the document reflected concerns of women: as persons, in relationships, in society, and in the Church. That draft was the last to quote directly from and to be genuinely reflective of women's actual voices.

The second draft of the letter, written in 1990, One in Christ Jesus: A Pastoral Response to the Concerns of Women in Church and Society, ${ }^{10}$ was not put to a vote by the NCCB, due to an international episcopal consultation that the Vatican called for. The third draft was written in response to what the Vatican called "implications for the Church universal." Called to Be One in Christ Jesus was presented to the entire body of bishops and returned to committee again after their input. ${ }^{11}$ The fourth version (One in Christ Jesus) was finally put to a vote. ${ }^{12}$ The bishops voted 137 to 110 in favor of publishing the draft, but, because it required a two-thirds majority to publish, it failed. ${ }^{13}$

A number of differences are evident between the first and fourth drafts, only a few of which there is space to comment on here. One striking difference, however, is that women's voices can scarcely be heard in the fourth draft-all direct quotes from women in the first draft were eliminated from One in Christ Jesus. ${ }^{14}$ The first draft had called for more study of the ministerial priesthood, while upholding current practice (largely on the basis of unbroken tradition) and called for expediting the study of admitting women to the diaconate. The

${ }^{8}$ While I can try to hear and internalize the categorical experience of others, and to hear them virtuously, I can only write from my own schema. I have found allusion to but no data that separates out the concerns about or responses to this document from women of various socioeconomic statuses, LGBT status, abilities/disabilities, or racial/ethnic groups.

${ }^{9} \mathrm{NCCB}$, Partners in the Mystery of Redemption.

${ }_{10}$ Origins 19 (April 25, 1990): 717, 719-40.

${ }^{11}$ Origins 21 (April 23, 1992): 761, 763-76.

${ }^{12}$ NCCB, One in Christ Jesus (Washington, DC: US Catholic Conference, 1992).

${ }_{13}$ Patrick Carey Pastoral Letters and Statements of the United States Catholic Bishops, vol. 6, 1989-1997 (Washington, DC: US Catholic Conference, 1998).

${ }^{14} \mathrm{NCCB}$, One in Christ Jesus. 
committee pointed out that women were already performing most of the functions of the diaconate through lay ministry and were "capable of accomplishing all of them." ${ }^{15}$ The fourth draft, while still calling for the study of the possibility of the diaconate for women, reaffirmed the Church's teaching on the male priesthood. One strong argument used in the fourth draft was that the priest was the sacramental sign of Christ and relied on "the natural symbol of gender."

This switch from using tradition as the main argument to a greater reliance on analogy was also evident in the area of inclusive language. While the first draft calls for inclusive language in liturgical and educational settings "whenever possible,"16 the fourth draft, while recognizing the need to specifically change terms such as men and brothers to more inclusive words, encourages caution, rejecting the "ideological overtones" surrounding the issue: "Especially we must recognize the normative nature of Christ's revelation to us that God is our Father and hence preserve the Trinitarian names. Such language is not merely metaphorical. It is analogical, that is, it expresses, albeit in an imperfect and limited way, the truth of the life of the Trinity."17

In summarizing the final, fourteen-page version of the pastoral (which was delivered to parishes in pamphlet form), the way the documents begin and end seems symbolic. The first draft begins with an account of the "Samaritan Woman" (John 4:39) as an example of women being among the first (if not the first) witnesses to Jesus's proclamation of the Kingdom of Heaven and the Resurrection. ${ }^{18}$ The committee then transparently recounts its membership, its charge from Vatican II, and the process through which the first draft was written. Partners closes with the call for implementation of its recommendations (rather than "empty words"), and the charge, "Thus, having heard the word, we must respond with imagination and courage to eradicate the injustice which keeps us from the full stature of Christ." It ends with Mary's proclamation of the Magnificat (Luke 1:46-55), which may be seen as a call to justice and to the overthrow of oppressive social order. The third draft (1992) begins with a truncated version of the first drafts, and includes the caveat that the bishops were now responding as the "authentic teachers of faith," not using consultants from the social sciences as they had in the pastorals on war and the economy: "We did not respond as empirical scientists following a rigorous method leading to scientific conclusions. Nor did we attempt with scientific accuracy to clarify all the issues and the causes of the concerns women raise."19

The fourth draft of the pastoral ends with the reiteration of the bishops' roles as teachers and ministers and their responsibility to make known the

${ }^{15}$ NCCB, Partners in the Mystery of Redemption, 75.

${ }^{16}$ Ibid., 78.

${ }^{17}$ NCCB, One in Christ Jesus, 26.

18 NCCB, Partners in the Mystery of Redemption, 1.

${ }_{19}$ NCCB, One in Christ Jesus, 1. 
wisdom of sacred scripture and the Church's tradition, which will "serve to strengthen our communion with one another in Christ Jesus." ${ }^{\text {20 }}$ Hence, that the fifth and final document (Strengthening the Bonds of Peace, 1994), begins the first paragraph by reiterating what women are not allowed to do (summarizing and affirming the teaching and practice that ordination is reserved for men) should come as no surprise. ${ }^{21}$

The NCCB added their affirmation of Pope John Paul II's praise of women's "necessary and irreplaceable" role in the Church. The pamphlet denounces discrimination and espouses equality but more strongly emphasizes the "diversity of gifts" offered by females and males. The second paragraph on the first page encourages our "brothers and sisters" (even this address indicates how tone-deaf the pamphlet is, by addressing it to "brothers" before the "sisters" whose issues it addresses) to accept and understand more fully the Ordinatio Sacerdoctales, the official teaching on the all-male priesthood. Acknowledging that the teaching had started a firestorm in some quarters, the bishops wrote, "some received the teaching with joy and peace. Others found acceptance difficult." The bishops continued, extending the invitation to strengthen the bonds of peace, "For certainly, all can agree that peace is a blessing we long for." 22 There is little doubt that the bishops longed for peace and that they envisioned that peace coming through women's acceptance of the teaching in a "peaceful" manner.

It is instructive that the directions for use and accompanying materials for the pamphlet were roughly three times the length of the pamphlet itself (forty-eight pages). ${ }^{23}$ Among the resources is advice that homilists should address the topics of women's equal dignity in ministry and family life throughout the liturgical year; "but, proceed with caution. Remember that the idea of women as partners with men is still new to many, and not always easily received." ${ }^{24}$ The bishops insist that dialogue is essential (although forbidden on the topic of women's ordination) and an instrument of peacemaking. "We can use dialogue to approach complicated, confusing, and often polarizing issues such as the topic of women ... in the Catholic Church." ${ }^{25}$ The bishops add, "the presence of opposing ideas is actually healthy." ${ }^{\text {"26 }}$ Hence, women's voices may be "heard" but only on certain topics. The section ends with signs of "progress," a survey of the many roles women were able to perform in the Church at that

${ }^{20}$ Ibid., 26.

${ }^{21}$ NCCB, Strengthening the Bonds.

${ }^{22}$ Ibid., 1.

${ }^{23}$ NCCB, Strengthening the Bonds of Peace, Resource Packet (Washington, DC: US Catholic Conference, 1994).

${ }^{24}$ Ibid., Section 3, 1.

${ }^{25}$ Ibid., Section 6, 1.

${ }^{26}$ Ibid., Section 6, 7. 
time. Unsurprising to anyone who visits a parish office or attends Sunday mass was the report that 85 percent of parish ministers were women. ${ }^{27}$

In a collapsed version of history, suffice to say that each draft was further removed, both literally and figuratively, from the hands of women, culminating in the final pamphlet being written by two (male) bishops. ${ }^{28}$ Each of the subsequent drafts was more reflective of the criticism, by some bishops but most strongly the Vatican, that the role of the bishops to teach had been abdicated and that the active listening posture, which had been adopted in the early days of the ad hoc committee, did not reflect the bishops' proprietary teaching role. ${ }^{29}$

\section{Fricker's Theory of Testimonial and Hermeneutical Injustice}

In examining whether an injustice was committed through the lens of virtue ethics, a definition of terms is in order. Virtue ethics, as understood here, ${ }^{30}$ means a form of normative ethics that emphasizes the development of virtues, particularly prudence, in an attempt to discern what attitudes and actions will bring about human flourishing and the common good. Both human flourishing and the common good are the result of just actions determined by right reason. Both just actions and right reason must take into account lived experience, as Fricker's theory does. I make the assumption here that Fricker's ethical theory, although secular, is compatible with the Church's long embrace of Thomistic/ Aristotelian teaching on virtue and ethics. This case will be centered on the cardinal virtues of prudence (perhaps more readily understandable in another common translation, practical wisdom) and justice. ${ }^{31}$

Fricker's theory, as outlined in her book, Epistemic Injustice: Power and the Ethics of Knowing, was a philosophical response to the influence of positivist linguistic analysis. ${ }^{32}$ She and other critics felt that particular philosophy lacked

${ }^{27}$ Ibid., Section 6, 10.

${ }^{28}$ Mich, "Sexism," 262.

29 Ibid.

${ }^{30}$ Space limitations preclude me from anything but a brief definition of virtue ethics here. Aside from Fricker's treatment in Epistemic Injustice, writings on virtue ethics abound, beginning with Aristotle's Nicomachean Ethics through Aquinas's Summa Theologica to current books, including Roger Crisp and Michael Slote, Virtue Ethics (Oxford Readings in Philosophy) (Oxford: Oxford University Press, 2007).

${ }^{31}$ A description of the Church's long embrace of virtue ethics, again, is beyond the scope of this paper. For one source of the appropriateness of applying virtue ethics to the actions of the bishops, see the 1993 Catechism of the Catholic Church (http://www.vatican.va/archive/ENG0015 /_INDEX.HTM), Article 7, which includes definitions of just, prudent, and virtuous behaviors. The tradition of Christian theological ethicists continues today with Catholic moral theologians such as Margaret Farley, James Keenan, and Bryan Massingale.

${ }^{32}$ For an extensive discussion of positivist linguistic analysis (also called logical positivism), which rejects metaphysics and has an empirical basis, and its relationship to other philosophical 
agential responsibility for injustice and neglected the study of ethics. Her theory aimed to make epistemology more relevant to current experience. Fricker says, "epistemology is gradually being broadened . . . to cultivate a closer relationship to actual epistemic practices ... . when we take our primary subject matter to be those human practices through which knowledge is gained, or indeed lost." ${ }^{33}$ So, while not directly tied to theology, her work is applicable in terms of how knowledge is shared, understood, built, and conveyed. Since one of the foci of Catholic theological ethics is experience, her focus on the injustices in socially situated, lived experience would include the Church as a place where the study of ecclesial knowledge (or ecclesial epistemology) would occur.

Culpability for some of Fricker's injustice is largely agential (meaning that the injustice is committed by one person to another ${ }^{34}$ ) as is the case in testimonial injustice. Testimonial injustice occurs when one person disbelieves another because "prejudice causes a hearer to give a deflated level of credibility to a speaker's word." ${ }^{35}$ So, one person might disbelieve another due to differences in gender/sexuality, race/ethnicity, social class, or other conceptual divisions of humanity that make one person feel another is inferior.

Other injustices are largely structural, in which society as a whole (or a representative or segment of that society in power) commits the injustice. In hermeneutical injustice, people are disbelieved because, "a gap in collective interpretive resources puts someone at an unfair disadvantage when it comes to making sense of their social experiences." ${ }^{36}$ In other words, this sort of injustice occurs when, usually due to closely held power structures (such as the Church's hierarchy), there is a lack of input from marginalized groups, so that neither group has language to serve as a basis for belief in, or understanding of, the experiences of the marginalized group. We are all epistemologically blocked.

Simply stated, Fricker's injustice occurs whenever prejudice on the hearer's part, caused by the hearer's stereotypic judgment of the speaker or "knower" in Fricker's terminology, causes the hearer to give the knower less credibility. Therefore, the knower is not "heard," resulting in the primary harm of unjustly being disbelieved and thus being devalued as a person. Secondary harm occurs both in whatever the practical, immediate consequences of being disbelieved, discredited, or disregarded might be and also epistemologically, in being prematurely removed from further dialogue or access to the capacity to know. To be clear, in Fricker's terminology, the "hearer" is the person(s) listening to and

movements, see A. J. Ayer, Philosophy in the Twentieth Century (New York: Random House/ Vintage, 1984).

${ }_{33}$ Fricker, Epistemic Injustice, vii.

34 While there is some philosophical debate about structures acting as agents, I use Fricker's individual meaning here.

35 Fricker, Epistemic Injustice, 1.

36 Ibid. 
judging the speaker. In this particular case, the "hearer" refers to the Church hierarchy. The "knower" is the expert witness, or the person who speaks from their own lived experience-in this case, the "knowers" are Catholic women.

Fricker uses the example of the trial in To Kill a Mockingbird by Harper Lee to explain testimonial injustice. ${ }^{37}$ In that trial, a black man, Tom Robinson, is wrongly accused and convicted of the sexual assault of a white woman, in spite of the facts presented, which proved that Tom could not have committed the crime. So, despite physical evidence to the contrary, because Tom was black, the white jurors who heard his testimony judged him to be either incredible or untrustworthy and found him guilty of a crime he did not commit. The primary harm done was that he was not "heard" as any human being should be. The secondary harm in this case was much greater-he was murdered by vigilantes before he could appeal his sentence.

As another example, when my son-in-law brought his baby to the doctor because he was concerned about an unusual rash, a white pediatrician, who was not the baby's regular doctor, explained to him that it was important to change a baby's diaper frequently to avoid diaper rash. My son-in-law (who has many tattoos and is Puerto Rican) patiently explained that he was a stay-athome parent, that this was his second child, and that he had managed to avoid any serious rashes through the baby's first year. The pediatrician remained skeptical — my son-in-law was less credible in her opinion than a stay-at-home mom would be-or perhaps less credible because of his tattoos or ethnicity. The primary harm was that he was doubted as a competent parent. The secondary harm, had he not come back the next day to see the regular pediatrician and gotten a prescription for the rash, would have been more pain and discomfort for the baby.

To illustrate hermeneutical injustice, in which society as a whole is discriminatory toward marginalized groups, Fricker uses the experience of sexual harassment. Prior to the mid- to late twentieth century, men in Europe and America held power closely, with limited input from women in the realms of academia, law, religion, and politics. Because there were few women in the power structure, they were hermeneutically marginalized, unable to participate equally in the practices through which social meanings were generated and shared. Because men were only familiar with what we now call sexual harassment from their own point of view, it was inadequately conceptualized in society and therefore unable to be really shared and understood. In addition, because of prevailing attitudes of guilt and shame, women did not readily discuss the harassment, further hampering the concept development. The harm done to many women, beyond being disbelieved or misunderstood, was both physical and psychological. It was not until consciousness-raising groups were initiated

${ }^{37}$ Harper Lee, To Kill a Mockingbird (Philadelphia: J. B. Lippincott, 1960). 
during the women's movement of the 1960s and 1970s that women began to discuss and to name this phenomenon. ${ }^{38}$

In addition, though generally unnoticed, in the case of hermeneutical injustice, not only is there situated hermeneutical inequality (in which members of the marginalized group are unfairly disadvantaged in rendering themselves intelligible) but there is also harm done to the hearer. The hearer, who is part of the dominant group, also suffers from hermeneutical lacuna and cognitive disablement, or the inability to understand certain concepts that we have no words for. This paper discusses the application of virtue ethics to this idea (in a philosophical sense) and the harm to full communion (in a theological sense) later. For now, suffice it to say that in hermeneutical injustice, prudence is lacking, experience is disbelieved, common good is thwarted, truth is not understood, and justice is not served. With that as the context of testimonial and hermeneutical injustice, I apply Fricker's theory to examine the case in point, the history of the creation of the pastoral letter on women's role in the Church.

\section{Application of Fricker's Theory to the NCCB's Pastoral on Women}

In hindsight, it is clear where the pastoral went awry. In his encyclical Mater et Magistra, (St.) Pope John XXIII, building on the work of Joseph Cardijn, advocated the look, judge, act model (based upon the virtue of prudence, right reason applied to action, according to Aquinas), as a way for the Church to undertake the social action called for by the Council. ${ }^{39}$ The first step of prudence is to look, taking good counsel through inquiry. In our case, this was justly undertaken by the original NCCB ad hoc committee, as demonstrated by the questions they asked women and the broad net they cast for their survey. The second step is to judge what you have discovered in your inquiry. Again, this appears to have been done justly through the long process of listening and producing the first draft of the letter, which was faithful to the lived experience of the women surveyed. The third step is to act upon what you have found and

${ }^{38}$ One might have some confusion here on the difference between testimonial and hermeneutical injustice in the case of Tom Robinson. Certainly, while structural prejudices influenced the jury, Tom knew and understood that he was not guilty, as did members of the jury. There was language developed that all parties could understand-it was simply overridden by prejudice. If the injustice were hermeneutical, Tom would not just be disbelieved, but he would be unable to adequately express or perhaps even understand what had happened. Tom both knew and understood what had happened, as did many members of the white community.

${ }^{39}$ Mater et Magistra: Encyclical of Pope John XXIII on Christianity and Social Progress, May 15, 1961, \#236, http://w2.vatican.va/content/john-xxiii/en/encyclicals/documents/hf_j-xxiii_enc _15051961_mater.html; Joseph Cardijn, "See, Judge, Act—Fifty Years of Catholic Social Practice," http://www.cardijn.info/2011/05/see-judge-act-fifty-years-of-catholic.html; and Bernard V. Brady, Essential Catholic Social Thought (Maryknoll, NY: Orbis, 2008). 
judged - and this is where it appears injustice occurred. Recall that at the end of the first draft, the ad hoc committee called for actions, among which were: changing some aspects of Church language; seriously studying and discussing the all-male priesthood and diaconate; offering contrition for past sins against women; and taking on, in Margaret Farley's words, an "attitude of epistemic humility" (the realization that no one is omniscient) when listening to women. ${ }^{40}$ Sadly, most of these actions were never undertaken - and some that were, such as substitution of inclusive language in the liturgy, have reverted to where they were before the first draft.

If the ends of virtuous conduct are the common good and human flourishing, the first step in applying Fricker's theory of testimonial and hermeneutical injustice to the pastoral on women would be to recognize that the flourishing of all is diminished by the exclusion of any. Aside from the women who were and are harmed by the actions of the bishops (in being denied their credibility as knowers), those in power are also excluded from the fullest grace of the Catholic communion by their failure to understand the language of marginalized groups. ${ }^{41}$ While Fricker depends upon philosophical models of the common good such as Aristotle's, in which the flourishing of the community and the flourishing of individuals are deeply connected, our Catholic tradition of Eucharist makes our mutual dependence even more clear — we are joined, body and soul, with Christ and one another, so the diminishment of any is injurious to all. In this case, it appears that somewhere between the first and fourth drafts, testimonial injustice occurred when some bishop(s) and/or curial official(s) denied the validity of the fourth pillar of Christian ethical reflection, lived experience. We don't have a name to go with the agent or agents who made this decision, but we do know that the words of women were both literally and figuratively erased from later drafts, deemed not credible enough and/or sincere enough to hold truth. At that same stage, women were removed from the hearing process. Thus, hermeneutical injustice occurred also, because those with teaching authority are the ones who have structured our collective ecclesial understanding, and that ecclesial understanding seemed to be the barrier that women could not (and the bishops would not) breech.

Fricker acknowledges that many virtues are historically contingent, and therein lies the question of culpability. The degree of culpability is determined

${ }^{40}$ Margaret A. Farley "Ethics, Ecclesiology, and the Grace of Self-Doubt," in A Call to Fidelity: On the Moral Theology of Charles E. Curran, ed. James J. Walter, Timothy E. O'Connell, and Thomas A. Shannon (Washington, DC: Georgetown University Press, 2002), 55-75. Farley says that theologians must look not only to tradition, Scripture, reason, and their own experiences but to the historical, social, cultural, and spiritual experiences of all the faithful. She urges the leaders of the Church to listen with "epistemic humility" thus "enabling the voices of its members" (60).

${ }^{41}$ When we say that the groups do not understand one another's language, it is not the failure to understand the words but the inability or failure to accept the experience conveyed by the words as worthy or valid. 
by what a reasonable person of the period, practicing prudence or practical wisdom, should have known. Thus, in the case of the bishop's letter, there is culpability on the part of the Church hierarchy in that the initial ad hoc committee acted as virtuous hearers in giving credence to women's experience by listening justly, prudently, and charitably. So, we could have reasonably expected the Vatican hierarchy and the larger group of American bishops to act in the same way. The questions asked of women before the first draft allowed for a correction of historical biases, not just by bringing in women as knowers, but also by having women as partners, along with the historically male hierarchy, among those who were the hearers. Fricker describes the effect of historical biases: "Let us say that when there is unequal hermeneutical participation with respect to some significant area(s) of social experience, members of the disadvantaged group are hermeneutically marginalized. The notion of marginalization is a moral-political one indicating subordination and exclusion from some practice that would have value for the participant." ${ }^{42}$

This may lead to cognitive disablement (an inability to understand or learn in a particular area) of the knower and the hearer. This occurs both because the Church may lack a recognition of an experience (such as being a woman) and because all may lack the language or communicative tools to describe the experience. Also, being part of that marginalized group may lead to the stunting of ecclesial development, and due to this gap in understanding and the failure of the dominant Vatican curial culture to remove obstacles and/or build bridges, do epistemological harm to both groups. Thus, women are prevented from having any official standing to articulate their experience. Not only that but they are also removed from both the ecclesial conversation and from the inner circles in which they might become hearers, and so they remain unable to join the dialogue and gain standing. Therefore, the whole Church is prevented from flourishing, and a remedy is called for. Others in the Church have and should propose other solutions: I propose one remedy, virtuous hearing, from Fricker's model.

\section{Applying Fricker's Virtuous Hearing with a Catholic Sensibility}

In looking toward a remedy, I take inspiration from Christian liberation theologies, centered on the dignity of the human person, in which marginalized groups seek their rightful place at the table. Bernard Brady writes that when we look at approaches to questions of social justice, we often ask, "Ought we work to change systems, structures and laws? Or ought we work to change people's hearts and minds?" 43 To Brady, it is not an either/or, but a both/and. He

${ }^{42}$ Fricker, Epistemic Injustice, 151 (emphasis added).

${ }^{43}$ Brady, Essential Catholic Social Thought, 179. 
addresses the universal good that liberation theologies can bring to the Church, using language that can help us understand how, as Fricker says, "two streams of input - collective and individual—continually generate a person's moral sensibility" 44

It is no small feat to overcome testimonial and, especially, hermeneutical injustice. Canadian theologian Bernard Lonergan speaks about the difficulty in overcoming our collective blind spots. Much like the danger posed to a researcher in a single blind study, the uncritical, biased mind sees only evidence that confirms its own thinking and beliefs. Lonergan asks, "How is a mind to become conscious of its own bias when that bias springs from a communal flight from understanding and is supported by the whole texture of a civilization?" 45

In order to bring about testimonial justice through virtuous hearing, we must realize that "in testimonial exchanges, for hearers and speakers alike, no party is neutral; everybody has a race, everybody has a gender. . . . What is needed ... is a corrective anti-prejudicial virtue that is distinctively reflexive in structure." ${ }^{\prime 46}$ For those who may be part of a hierarchical structure, Fricker warns of the strong role that social identity plays. ${ }^{47}$ "The virtuous hearer, then, must be reflexively aware of how the relation between his social identity and that of the speaker is impacting on the intelligibility to him of what she is saying and how she is saying it." 48

A prerequisite to fighting hermeneutical injustice is being aware of our own identity, and the unconscious rights, privileges, stereotypes, and psychosocial baggage that accompany that identity. While testimonial justice can become reflexive practice, applied to particular subjects, or knowers, hermeneutical injustice must be developed objectively. Fricker says that we need to learn to allow for the possibility that, due to the real, lived experience of another, there might be more than one valid interpretation of truth. This is not the same as pluralism-it merely acknowledges that we have only seen the world through our own eyes. We must go out of our way, above and beyond, to ask if "what the speaker is struggling to articulate would make good sense if the attempt to articulate it were being made in a more inclusive hermeneutical climate—one without structural identity prejudice. . . The guiding ideal is that the degree of credibility is adjusted upwards to compensate for the cognitive and expressive

${ }^{44}$ Fricker, Epistemic Injustice, 82.

${ }^{45}$ Elizabeth A. Morelli and Mark D. Morelli, eds., The Lonergan Reader (Toronto: University of Toronto Press, 1997), 39.

${ }^{46}$ Fricker, Epistemic Injustice, 91.

${ }^{47}$ In Racial Justice and the Catholic Church (Maryknoll, NY: Orbis, 2010), Bryan Massingale says of the "unconscious" nature of a cultural stereotype that its acquisition may not be explicit: "It is learned, internalized and used without an awareness of its source" (28).

${ }^{48}$ Fricker, Epistemic Injustice, 168. 
handicap imposed on the hermeneutically marginalized." 49 This must be done consciously, at first, but, if practiced over time, our sensibility can be reconditioned, through sufficient corrective experience, to become habitual. Might one who practices Farley's epistemic humility, allowing the voices of others to have credence, be on the path to virtuous hearing? How could individual members of the Church, bishops, and the collective of the magisterium begin this difficult task? Each of us needs to cultivate, through both experience and right thinking achieved through prudence, an openness to become moral and ethical people who try to correct for society's identity prejudices. ${ }^{50}$

Fricker says that virtuous hearing can be acquired, like all virtuous behavior, through a purposeful habituation of giving the other the benefit of the doubt. If what the knower says makes good sense and seems to be a truthful account (we should even risk overcompensating toward this end), we should make every attempt to believe her/him. "A reflective, critical social awareness . . . is a corrective anti-prejudicial virtue that is distinctively reflexive in structure . . . and is acquired, through practice, until it becomes second nature."51 She says that the virtuous hearer must train themselves, though dialogue and experience, to have a generous (we might say charitable) disposition toward the knower, and to adjust our credibility upward to correct for hermeneutical marginalization. That the NCCB ad hoc committee appeared to listen generously and with epistemic humility in accepting the accounts that women gave of their lived experience during the period lasting through the writing of the first draft of the pastoral letter on women proves that it could and should have been done at that time and can and must be done now.

It is difficult enough for us to become virtuous hearers as individuals - for institutions, it will be even harder. A commonsense first step (which the NCCB took when gathering information for and writing the first draft) would be that members of the marginalized group (women) be invited to be among the hearers (Church hierarchy). During Pope Francis's papacy, there has been renewed talk regarding women in leadership roles including, perhaps, as cardinals (who, at times in Church history, didn't necessarily need to be ordained). ${ }^{52}$ But even without women as cardinals, if women are admitted to the top roles that laity can occupy and also invited to be "cultural" advisors to the pope and magisterium, a more open attitude would be likely.

49 Ibid., 170.

${ }^{50}$ For this insight and for my introduction to Fricker, I am indebted to Melissa Shew for a summer 2012 doctoral philosophy seminar at Marquette University.

${ }^{51}$ Fricker, Epistemic Injustice, 91.

${ }^{52}$ See Luke Hanson, SJ, "Cardinal Marx on Francis, the Synod, Women in the Church, and Gay Relationships,” America, January 22, 2015, http://americamagazine.org/issue/cardinal-marx -francis-synod-women; and Joshua J. McElwee, "Vatican Spokesman: Female Cardinals "Theoretically Possible," National Catholic Reporter, November 4, 2013, http://ncronline.org/blogs/ncr -today/vatican-spokesperson-women-cardinals-theoretically-possible. 
Perhaps one of the most palatable ways for the hierarchy to approach virtuous hearing might come through the broadening of an ecclesial process of "reception," a historical, theological concept described by Richard Gaillardetz and others that lies fully within Church tradition. ${ }^{53}$ Reception has usually referred to the laity's acceptance or rejection of the teachings of the bishops. But Gaillardetz imagines a more dialogical process. This doesn't negate the teaching role of the bishops - in fact, good teachers change both how and what they teach in response to new discoveries, the experiences of students they are teaching, and the signs of the times. Good teachers listen to and learn from their students. Good teachers also admit mistakes. The bishops themselves alluded to this in the closing section of first draft of the letter, writing, "thus, having heard the word, we must respond with imagination and courage to eradicate the injustice which keeps us from the full stature of Christ." ${ }^{54}$ Farley agrees that the Church should return to the practice of hearing the faithful and teaching through reception..$^{55}$ But, in practicing reception, she urges all in the Church to pray for what she calls an underused gift of the Holy Spirit, the grace of selfdoubt. To begin a process of hearing virtuously, Church teaching offices, using that grace of self-doubt, must:

admit past mistakes, refuse to collapse the teaching role of bishops into the teaching role of the papacy, consult widely on moral matters, recognize that discernment is a process, revise procedures for overseeing theological work, and overall, introduce a more communal form of discernment in the Church. ... The grace of self-doubt is what allows for epistemic humility, the basic condition for communal as well as individual moral discernment. . . It is unlikely that official moral teachings can be received by members of the church whose experience of moral obligation are dismissed or denied. ${ }^{56}$

${ }^{53}$ In "The Reception of Doctrine: New Perspectives" (in Authority in the Roman Catholic Church, ed. Bernard Hoose [Surrey, UK: Ashgate, 2002], 95-114), Richard Gaillardetz describes what the practice might look like in today's Church: "In the first moment, we begin not with laws and doctrines, but with the lived experience and testimony of the Christian community." He continues, "This suggests that the process of doctrinal teaching actually begins with the magisterium receiving the lived faith of the people prior to giving that faith any official formulation in law, ritual, or doctrine" (7). It represents a dialogue among the community of the faithful. He points out the benefit of reception to marginalized groups: "The stance of those in Christianity who either live in exile' or at least 'in the margins,' for example, those women who feel oppressed and excluded by the tradition-must also be given voice in the process for doctrinal reception" (4).

${ }^{54}$ NCCB, Partners in the Mystery of Redemption.

${ }^{55}$ Farley describes the practice of hearing the faithful and teaching through the process of reception, wherein moral insights of the Church must be "informed, critiqued, nurtured, chastened, but finally freed for communal and individual moral action" ("Ethics, Ecclesiology, and the Grace of Self-Doubt," 66).

${ }^{56}$ Ibid., 61, 68-69. 
Virtuous hearing must be a two-way street, and it is incumbent upon those in the marginalized groups to try to hear the members of the hierarchy virtuously, trying to adjust credibility, and to hear them in the most charitable and loving way, trying to give each his/her due (which is only just). However, it is incumbent upon the powerful to begin the process both immediately and honestly. I would encourage a conversation on virtuous hearing, which might include exploration of an adaptation of the ancient Church practice of doctrinal reception, practiced with the grace of self-doubt (or epistemic humility), as one way for Church leaders to hear the faithful virtuously. But, in whatever way the Church approaches virtuous hearing, the practice of trying to hear virtuously is one that might be successfully used by the hierarchy in dealing with groups other than women that feel marginalized within the Church.

Finally, as to where to begin the enormous task of "hearing" the experience of the faithful, Fricker might point us back to Aristotle, who said that the training of a virtuous person occurred through habituation and practice: "But virtues we do acquire by first exercising them, just as happens in the arts. Anything we learn to do we learn by the actual doing of it; people become builders by building and instrumentalists by playing instruments. Similarly, we become just by performing just acts, temperate by performing temperate ones, brave by performing brave ones." ${ }^{.57}$ And, with the grace of God, we may become virtuous hearers through the practice of virtuous hearing.

Mary Carlson is a clinical instructor in the College of Education's Department of Educational Policy and Leadership at Marquette University. She supervises student teachers in the field and teaches a number of classes, but the one closest to her heart centers on teaching children with exceptional needs. She is also a candidate in Marquette's Interdisciplinary PhD program, with a focus in theology, philosophy, and special education. She completed her dissertation "Special Education as a Moral Mandate in Catholic Schools" in 2016. Her research interests center on justice for marginalized groups in schools, the Church, and society.mary.carlson@marquette.edu. 